\title{
The Dangers of Hoaxes in Building Civil Society in the Era of the Industrial Revolution 4.0
}

\author{
Muhamad Basitur Rijal ${ }^{{ }^{*}}$,Hisam Ahyani ${ }^{2}$, Abdul Basit ${ }^{3}$ \\ 1* Doctoral Program at Institut Agama Islam Negeri Purwokerto, Indonesia \\ 2 Lecturer at Sekolab Tinggi Agama Islam Miftabul Huda Al Azhar (STAIMA) \\ Kota Banjar, Indonesia, and Doctoral Program in Islamic Law UIN Sunan Gunung \\ Djati, Indonesia \\ 3 Professor Da'wah and Communication Sciences, State Islamic Institute Purwokerto \\ (IAIN) Purwokerto, Indonesia \\ Corresponding Author: ${ }^{1 *}$ basithelbari@gmail.com

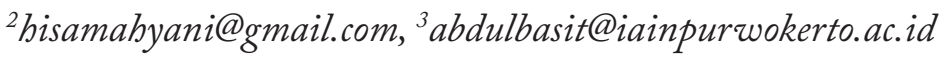

Article

Abstract

History:

Civil society (civil society) as the ideal structure of society's life that is aspired to, but building a civil society is not easy.

Submit:

2021-02-22

There are preconditions that must be met by the community in making it happen. Coupled with technological advances in the era of the Industrial Revolution 4.o like today, where information can spread easily through various online media unlimitedly in spreading hoaxes. This research seeks to uncover

Publish:

2021-04-30 the dangers of hoaxes in building civil society. This research uses descriptive analytical method by examining the sources of literature related to building civil society in the Industrial Revolution 4.o. This research found that the public space is a means of free speech; democratic behavior; tolerant; pluralism; and social justice can shape civil society. whereas the impact of hoax news greatly affects the way people perceive a certain issue, so that people cannot distinguish which news is real or fake news which causes them to be incited by fake news that is spread.

Keywords: Hoax, Civil Society, Era of Industrial Revolution 4.0 
Journal Homepage http://ijssr.net/index.php/ijssr

This is an Open Access article under the CC BY SA license

https://creativecommons.org/licenses/by-sa/4.0/

Published by

Indonesian Academy of Social and Religious Research

\section{Introduction}

The term civil society has recently become a hot term and is very interesting to be discussed, especially among people in Indonesia. Civil society is something that is expected to be able to grow and develop in the life of society in the future, although many people do not know what the real meaning of this term (civil society in Islam) means. According to Mawardi's view, he explained in his scientific research that civil society is one of the characteristics of a group that is guided by religious power as its main source, namely moral values and ideas and ways of behaving within the sphere of diverse community life in order to be able to live peacefully, mutually. trusting, and full of tolerance so that a moral, equal and cultured society grows. ${ }^{1}$ In civil society it is full of "human values" whose meaning is comprehensive and broad. The goals of civil society itself have been compiled as perfectly as possible by the Prophet Muhammad SAW, in the Medina Charter which conditions for human values, so as to create a harmonious, peaceful and happy society. Another term civil society is civil society, which is a concept that originated in the history of the West which was originally introduced in the 18th century by a Scottish philosopher named Adam Ferguson as quoted by Ibrahim in his research entitled "The Formation of Civil Society in Indonesia through Civic. Education".

Thus, as a result, the view of civil society is very appropriate if it is expected to develop normatively in community life in the future (in the future). This is because people's lives continue to change along with the times like today (era of disruption 4.0), which results in a loss of trust in others, and a fading sense of tolerance in society and the fading of the values of social care among others.

1 Imam Mawardi, "Dimensi-Dimensi Masyarakat Madani: Membangun Kultur Etika Sosial," Cakrawala: Jurnal Studi Islam 10, no. 2 (December 15, 2015): 159.

2 Farid Wajdi Ibrahim, "Pembentukan Masyarakat Madani Di Indonesia Melalui Civic Education," Jurnal Ilmiah DIDAKTIKA: Media Ilmiah Pendidikan Dan Pengajaran 13, no. 1 (August 1, 2012), https://doi.org/10.22373/jid.v13i1.469.the Islamic thinkers usually refers to the condition of civil society such as on the condition of Medina under the leadership of the Prophet Muhammad $a^{1}{ }^{1}$ allallÄh â $€^{\sim}$ alayh wa Sallam. Ideal concept of civil society is driven by a variety of many aspects including the pattern of the life of society, nation that refers to the rule of law, human rights, and respect for diversity in all its forms (pluralism 
In building civil society life, according to the view of Muhamad AS Hikam ${ }^{3}$ as quoted by (Ibrahim, 2012: 135) explains that this civil society is a society in which they must have several characteristics including characteristics (sincerity, freedom, belief and also independence) which are bound by legal values and norms that are obliged to be obeyed by all citizens. society in a particular place.

However, whether we want it or not, we must realize together that the development of globalization that is taking place especially in Indonesia, as it is today, has an impact (strong influence) on people's lives. In the advancement of science and technology, it has given birth to an open society, thus making the exchange of information more rapid so that people can more freely access all information and all kinds of activities in various parts of the world. From this, a sense of dissatisfaction arises if they are not actively engaged in disseminating information to other people as well. This behavior is in the world of psychology according to the research results found by Stepanus Sigit Pranoto ${ }^{4}$ is the narcissistic behavior of the Internet and social media that should be used in a positive way, such as spreading knowledge that can be used by everyone, instead it is used for negative things, one of which is by spreading fake news or hoaxes (pronounced "hoks").

Dilasnsir from (muslimdailynet) as quoted by (Afrilia, Triana, and Rokim 2018: 28-29) said that there are 3 human forms that cause people's lives to be inseparable from the term hoax, namely people who spread fake news with the aim of destroying people's lives Muslim; people who easily get the news and quickly spread it to others without first knowing whether the news is true or not; and people who easily prejudice and immediately draw conclusions and spread their prejudices to others. These three human forms are dangerous human characteristics that can destroy national unity and integrity. ${ }^{5}$

The spread of hoaxes which are especially spread very easily like "mushrooms in the rainy season" is not only intended to deceive the community, but even worse is used by unscrupulous people who intend to destroy and divide the unity and integrity of the nation and state. In the research launched by (Siswoko, 2017),

3 Muhammad AS Hikam, Demokrasi Dan Civil Soceity (Jakarta: LPES, 1996), 27.

4 Stepanus Sigit Pranoto, "Inspirasi Alquran dan Hadis dalam Menyikapi Informasi Hoax," $A L$ QUDS : Jurnal Studi Alquran dan Hadis 2, no. 1 (June 22, 2018): 29-50, https://doi.org/10.29240/ alquds.v2i1.371.

5 Sella Afrilia, Rumba Triana, and Syaiful Rokim, "Pandangan Al-Qur'an terhadap Realitas Hoax," Al - Tadabbur: Jurnal Ilmu Al-Qur'an dan Tafsir 3, no. 01 (June 7, 2018): 28-29, https://doi. org/10.30868/at.v3i01.254. 
several well-known media in Indonesia such as newspapers (Kompas and The Jakarta Post) reported that the Indonesian state had complex problems in the spread of hoaxes.. ${ }^{6}$ So terrible was the impact (strong influence) that resulted from the spread of this hoax that observers said a hoax was the same as a "cancer" that undermined democracy. Sayyidina Ali bin Abi Thalib karromallohuwajhah also once said that if a crime has enveloped a period followed by many unjust people and one person who has good prejudice to strangers he does not know, then he will easily be fooled (deceived). ${ }^{7}$

As a result, researchers will uncover an issue Hoax in this research is one of the diseases that will hinder the growth and development of people who try to build civil society life so that the dangers and ferocity of this hoax in hindering development in realizing civil society in the era of industrial revolution 4.0 such as today which is full of peace, mutual trust and full of tolerance. Despite the fact that fake news or hoaxes existed before the internet appeared as in Islamic history, when the death of the third caliph (Utsman bin Affan RA) due to hoax information, he was slandered for having committed corruption, until he was killed by the victim who was instigated by the hoax. However, fake news in the past could not be spread easily due to the limited information media facilities, only word of mouth. Ironically, in this modern era (era of disruption 4.0), there are various facilities for the media of information for the public which are even turned into something negative by irresponsible people by spreading hoaxes that are very easily trusted by the wider community. Therefore, this study is very unique and interesting so that researchers are interested in discussing the dangers of hoaxes (fake news) in building civil society, especially in Indonesia in the era of the Industrial Revolution 4.0..

\section{Literature Review}

As the research proclaimed by (Susilo, Afifi, and Yustitia 2020) that Hoax or fake news in Indonesia, in particular, is increasing sharply day by day along with several uses in social media. For example, in the run-up to the general election in 2019, where the intensity of political hoaxes was increasingly prevalent in

\footnotetext{
$6 \quad$ Kurniawan Hari Siswoko, "Kebijakan Pemerintah Menangkal Penyebaran Berita Palsu Atau 'Hoax,” Jurnal Muara Ilmu Sosial, Humaniora, Dan Seni 1, no. 1 (May 10, 2017): 13-19, https://doi. org/10.24912/jmishumsen.v1i1.330.

7 Sabiruddin, "Saring Sebelum Sharing, Menangkal Berita Hoax, Radikalisme Di Media Sosial," AL MUNIR: Jurnal Komunikasi Dan Penyiaran Islam 0, no. 0 (June 1, 2019): 23, https://doi. org/10.15548/amj-kpi.v2i1.486.
} 
Indonesia. Hoaxes can target anyone (youth, children, parents), but Susilo aimed specifically at this hoax in his research for competing candidates (election-19). With the presence of this hoax has the potential to trigger conflicts in society and can divide the unity of the Indonesian nation. Many things have been done by the government in an effort to eradicate this hoax. As a result, eradication requires the involvement of many parties, including through community organizations (ormas). The results of his research prove that of the various numbers of community organizations that are relevant to this topic (hoaxes) are all organizations that are researched in supporting efforts to eradicate hoaxes. Hoax is counterproductive in the life of the nation and state. All organizations have also done many things according to their fields. However, they (sheep complainants) also have limitations, therefore the Indonesian government is most responsible for the efforts to eradicate these hoaxes. In this study, it was found that the uniqueness of Islamic organizations was that these organizations were treated unfairly in eradicating these hoaxes. ${ }^{8}$

For example, in the case of the handling of the Covid-19 pandemic virus, which until now continues to spread the virus, especially in developing countries such as Brazil and India, where the research launched by Wicaksono found that the policy in handling this case was the prerogative of each country. ${ }^{9}$ Furthermore (Putri, Pambudi, and Adriyanto 2020) in their research that the recent tensions from the American side (the South China Sea) which is a challenge for our beloved country (Indonesia) need a reliable and efficient government policy to prevent These tensions include strengthening the approval of the Code of Conduct and accommodating the ASEAN forum and also the need for meetings with Asian countries to minimize the emergence of war over the seizure of the South China Sea. ${ }^{10}$ In facing the current of globalization like this, in the results of his research Evi Ni'matuzzakiyah ${ }^{11}$ proves that where there are many gaps between practice

8 Muhammad Edy Susilo, Subhan Afifi, and Senja Yustitia, "Peran Organisasi Masyarakat Sipil Dalam Pemberantasan Hoaks,” Eksos LPPM 2, no. 1 (December 17, 2020): 10-18, https://doi.org/10.31315/ eksos.v2i1.4150.

9 Raden Mas Try Ananto Wicaksono, "Review and Analysis of Current Responses to Covid-19 in Brazil and India: Period of January to July 2020," International Journal of Social Science and Religion (IJSSR), November 2, 2020, 81-112, https://doi.org/10.2020/ijssr.v1i2.11.

10 Erti Fadhilah Putri, Kukuh Setyo Pambudi, and Agus Adriyanto, "Analysis of the Increasing USChina Military Tension in the South China Sea and the Challenges for Indonesia," International Journal of Social Science and Religion (IJSSR), November 2, 2020, 187-98, https://doi.org/10.2020/ ijssr.v1i2.10.

11 Evi Ni'matuzzakiyah, "The Influence of Asmaul Husna Dhikr on Adolescent Emotional Intelligence," International Journal of Social Science and Religion (IJSSR), October 9, 2020, 47-54, https://doi. org/10.2020/ijssr.v1i1.7. 
and theory, it can be accommodated by habituating Asmaul Husna (great names) where various lessons from Asmaul Husna are in overcoming and increasing the emotional intelligence of Indonesian adolescents. Thus, with the source of the hoax, it is hoped that it can help minimize this dishonorable act, namely by spreading (fake news).

Research conducted by (Mansur et al. 2021) related to freedom of speech, especially in Indonesia, has emerged since the reform era. From this freedom of speech is a freedom which refers to the right to be able to speak freely without any pressure or certain limitations. With the presence of social media (medsos), which is widely used as a place to express themselves against their opinions (society) which is free and mostly done by Indonesians. As a result, the selfignorance of the Indonesian people itself has led to abuse by Indonesians who take advantage of this social media (medsos) by spreading unclear messages (the origin of the source) and not necessarily the originality of the news. ${ }^{12}$

Indonesia, which is a state of law where fake news is spread, will be charged with punishment in accordance with Law No. 11 of 2008 concerning electronic information and transactions in return for the actions of the spreader of the fake news. Furthermore, Khoirum Lutfiyah ${ }^{13}$ in his latest research (2020) proves that in the midst of a pandemic like today, hoaxes are indeed rife with various motives and modes of the hoax spreader. With fake news related to the spread of the Covid pandemic, people are restless and anxious (exhausted fear) to experience losses, this is where the role of the government is needed. Furthermore, research by (Muqsith and Muzykant 2019) where the hoax phenomenon is currently included in the realm of various lines including in the realm of democracy where this phenomenon is often referred to as the post-truth era with various demands for an all-digital era as it is currently developing with the message of information technology making difficulty in distinguishing between true news and fake news (hoax). As a result, this hox related to democracy has an effect on cohesion (clear relationship) between social life, especially in Indonesia.. ${ }^{14}$

Furthermore, Pratiwi Utami in his research explained that where political tensions in various countries in the spread of fake news that enter through social

12 Suraya Mansur et al., "Fake News on Social Media and Adolescent's Cognition," Jurnal ASPIKOM6, no. 1 (January 19, 2021): 29-41, https://doi.org/10.24329/aspikom.v6i1.827.

13 Khoirum Lutfiyah, "Hoax and Fake News During Covid-19: Is the Law Effective in Overcoming It?," The Indonesian Journal of International Clinical Legal Education 2, no. 3 (September 30, 2020), https://doi.org/10.15294/ijicle.v2i3.38422.

14 Munadhil Abdul Muqsith and Valerii Leonidovich Muzykant, "Effect Fake News for Democracy," Jurnal Cita Hukum 7, no. 3 (December 18, 2019): 307-18, https://doi.org/10.15408/jch.v7i3.12956. 
modes (medsos), Indonesian plural society can divide the ties of brotherhood, as a result, with a tendency related to exposing some truths and alienating people from belief. facts or hoaxes can be a threat to participatory democracy in an era of disruption like this. ${ }^{15} \mathrm{~A}$ person's behavior and thoughts can also be influenced by this hoax, this is as research found by (Adhiarso, Utari, and Hastjarjo 2018) where in their findings there is a strong influence in the meaning of fake news (invalid) which spreads through modsos for the nitizens, and strangely enough, when news of uncertain origin spreads very quickly and people easily believe in this hoax news, meaning that social media in Indonesia greatly influences the belief in this hoax news that spreads in online media. ${ }^{16}$

So that so far the novelty of this research has not been revealed regarding the dangers of hoaxes (fake news) in building civil society, especially in Indonesia in the era of the Industrial Revolution 4.0..

\section{Methods}

The type of research used by the authors in this study is the type of library research (library research). Literature study is a research technique by collecting various data and information from research literature sources and the writings of leading experts relating to the problems and objectives of this research. According to Danial and Warsiah, they argue that literature / libraries / books are information and the main source of research data to be analyzed and processed. ${ }^{17}$ Because this research is a literature review, the authors collect data and literature sources then observe and make an analogy of the research literature sources in order to obtain theoretical data. In addition, by using literature review, the writer can obtain information from the expected research steps, so that the study that the author makes is not the result of plagiarism or plagiarism. This study is also purely literal in nature, which can be called the descriptive method of analysis, which is a method that can be used in gathering various sources that discuss the

15 Pratiwi Utami, "Hoax in Modern Politics: The Meaning of Hoax in Indonesian Politics and Democracy," Jurnal Ilmu Sosial Dan Ilmu Politik 22, no. 2 (January 4, 2019): 85-97, https://doi. org/10.22146/jsp.34614.\\uc0\lu8221\{\}\{\\i\{\}Jurnal Ilmu Sosial Dan Ilmu Politik\} 22, no. 2 (January 4, 2019

16 Dendy Suseno Adhiarso, Prahastiwi Utari, and Sri Hastjarjo, "The Influence of News Construction and Netizen Response to the Hoax News in Online Media," Jurnal The Messenger 10, no. 2 (July 31, 2018): 162-73, https://doi.org/10.26623/themessenger.v10i2.782.

17 Danial and Warsiah, Metode Penulisan Karya Ilmiah (Bandung: Laboratorium Pendidikan Kewarganegaraan UPI., 2009), 80. 
same thing so that it can be used by the author to draw conclusions. From this explanation, it can be concluded that through this method the author tries to provide answers to the problems that occur by conducting critical analysis and reflective logic in order to get a thorough understanding of the dangers of hoaxes in building civil society.

\section{Result and Discussion}

\section{Hoax and the Danger of Its Spread}

Hoax is a term that is currently popular on the internet and social media which is used to refer to the term fake news or false information. The term hoax comes from English which means fake news or deceit with a lie. In simple terms, hoaxes can be interpreted as false information or news that cannot be proven. Afrilia, Triana, and Rokim in their research explained that basically hoaxes are used to fool others by creating fake news or information so that they have the right impression so that others can trust them.. ${ }^{18}$ There is another term that is often called hoax, namely fake news, but both refer to the same meaning, namely fake news or information. Actually, the term hoax has actually appeared since ancient times. However, the means of information media in spreading hoaxes in the past were limited to word of mouth, so that they were only for consumption for the surrounding community.

Today, as research is conducted by Alief Sutantohadi regarding the dissemination of news and information equipped with sophisticated internet and social media facilities. With the internet and social media, people are free to express their opinions, either orally or in writing, either through print or online media. ${ }^{19}$ The dissemination of information and news is very fast and can be reached by the world community. However, there is a negative impact of freedom of opinion on the internet and social media, that someone will easily disseminate various information without judging whether the information is right or wrong, so that it can build public opinion that causes divisions between people. In other words, hoaxes are one of the negative impacts of using the internet and social media that occur in society. With so many hoax news spreading, it makes it difficult for the public to distinguish whether the information he received is true

18 Afrilia, Triana, and Rokim, "Pandangan Al-Qur'an terhadap Realitas Hoax," 34.

19 Alief Sutantohadi, "Bahaya Berita Hoax Dan Ujaran Kebencian Pada Media Sosial Terhadap Toleransi Bermasyarakat," DIKEMAS (Jurnal Pengabdian Kepada Masyarakat) 1, no. 1 (2017), https://doi.org/10.32486/jd.v1i1.153. 
or just rumors. And what is worried is if the information or news that is spread is deliberately made by irresponsible people who aim to divide the unity and integrity of the nation.

Hoax according to (Rasywir and Purwarianti 2016) is dangerous news because it is able to mislead public opinion with the spread of fake news which is considered as truth. ${ }^{20}$ Moreover, the condition of Indonesian society in an era like today (industry 4.0) is currently being hit by various conflicts such as in terms of politics, ethnicity and religion, so it is not surprising that this hoax phenomenon continues to thrive with the spread of news or information that is inciting and provoking the public through the internet and social media. The dissemination of news or hoax information is not only by criminals, many of whom only share their opinions, as a means of seeking popularity, even just for fun. However, whatever the purpose of its spread, hoaxes cannot be justified because they are very detrimental to society and even the state.

One of the factors for the development of hoaxes in Indonesia in an era like today (industry 4.0) can also be caused by the lack of awareness of the public about the importance of literacy which causes people to be easily provoked by hoax spreaders without finding out the truth of this information, even many people who getting hoax information actually helps spread the news to others. Even though the government strictly prohibits and threatens hoax spreaders with penalties written in the 1945 Constitution article 28 paragraph (2) and article 45 paragraph (2) concerning the Law on Information and Electronic Transactions with a maximum imprisonment and fine of 1 billion. ${ }^{21}$ Coupled with the formation of a government cyber team that said it had removed thousands of negative content sites on the internet and social media. However, until now the government's efforts are still unclear, because the spread of information and hoax news is even more widespread. The government's efforts seem futile if there is no awareness from within the community itself and assistance from other components.

The results of research launched by Ruri Rosmalinda, he also revealed that apart from the lack of interest in reading from the public, there were several other factors that led to the development of hoaxes, namely because of the

20 Errissya Rasywir and A. Purwarianti, "Eksperimen Pada Sistem Klasifikasi Berita Hoax Berbahasa Indonesia Berbasis Pembelajaran Mesin,” Journal Cybermatika, 2016, /paper/Eksperimen-padaSistem-Klasifikasi-Berita-Hoax-Rasywir-Purwarianti/1bccbbff6d80643ec3bfb0e6c27cf7c4e23fc1 $8 f$.

21 Sabiruddin, "Saring Sebelum Sharing, Menangkal Berita Hoax, Radikalisme Di Media Sosial," 34. 
factor of communication tools and the state of society that was easily provoked. Furthermore, Rosmalinda was quoted as saying by Susanto and Muhamad Iqbal ${ }^{22}$ said that almost every community has a communication tool such as a cellphone that can be used as a source for seeking information from the internet and social media. Only by using smart phones that are easily accessible and affordable, people can access and even send various information on the internet and social media. In addition, the freedom to access information and disseminate information causes people to be easily provoked by hoax information, without first finding out whether the information received is true or false, then they can confidently spread the information they think is true to others. Whether they realize it or not, they themselves have become the perpetrators of spreading hoaxes..$^{23}$ Furthermore, Rosmalinda, as quoted by Ghandhi, said that this (related to hoaxes) made a global threat in Indonesia.. ${ }^{24}$

In addition, there are other causes of hoaxes, namely the first from the point of view of political interests. Like it or not, the term hoax has started to become a trend with the emergence of political issues. People persistently defend the interests of the rulers, they will humiliate political opponents to appear superior to their opponents even by spreading hoaxes. Both from an economic point of view, articles or content containing hoaxes will usually go viral on a site so that they become a source of income for hoax makers. Third, because of the boredom factor, so someone will make a horrendous news that is different from most in general. Fourth, because of the popularity factor. Because wanting to be famous and being popular makes someone do anything. Mockery, insults, ridicule or blasphemy from others will not be ignored for reasons of popularity, the more blasphemed, the more famous they are. And the last one is for rating reasons. Viral news will raise its rating so that people will compete to create content that can make people excited, one of which is hoax news.

From some of the factors above, Juditha explained in her research findings that coupled with the condition of the Indonesian people who easily believed in news without finding out the source and clarity of the information caused hoaxes

22 Susanto and Muhamad Iqbal, "Pengabdian Kepada Masyarakat Dalam Sinergitas Akademisi Dan TNI Bersama Tangkal Hoax Dan Black Campaign," CARADDE: Jurnal Pengabdian Kepada Masyarakat 2, no. 1 (June 11, 2019): 11, https://doi.org/10.31960/caradde.v2i1.119.

24 Al Mutia Gandhi, "Ancaman Hoax Terhadap Media Massa," AL-HIKMAH: Media Dakwah, Komunikasi, Sosial Dan Budaya 9, no. 1 (June 25, 2018): 33, https://doi.org/10.32505/hikmah. v9i1.1724. 
to continue to grow and develop in Indonesia. ${ }^{25} \mathrm{With}$ the hoax, Rusdiana also added that the public would be confused about which information to believe, this condition can be said to be the stage of "information bias" where the public will share information or news that is considered true.. ${ }^{26}$

\section{Concept of Civil Society}

Civil society or commonly known in English as civil society, where in Abraham's research is a concept that originated in the history of the West which was originally introduced in the 18th century by a Scottish philosopher named Adam Ferguson. ${ }^{27}$ The civil society is a reflection of the Medina society at the time of the Prophet Muhammad which refers to the order of goodness values (Al-Khair). There are several opinions from experts in interpreting the notion of civil society, such as Hikam's opinion which states that civil society is a group of members of society who can actively and practically solve social problems. In contrast to Gallner, who said civil society is an independent society and strong as a counterweight to the nation. Then, Victor as quoted by (Suroto, 2015: 665) in his journal states that civil society is a society that is not too bound by government regulations, so that it can act freely and independently but complement each other). ${ }^{28}$ Thus, it can be said that basically civil society is a group of people that are independent and composed of one soul, which complement and strengthen each other but are accompanied by obedience to the government..

In a concept discovered by Mawardi ${ }^{29}$ it is explained that among civil society, a group of people will be guided by religious power as the main source of moral values, ideas and ways of behaving in a diverse society in order to be able

25 Christiany Juditha, "Interaksi Komunikasi Hoax Di Media Sosial Serta Antisipasinya Hoax Communication Interactivity in Social Media and Anticipation” Pekommas, Vol. 3 No. 1, April 2018: 31-44 (2018): 42, http://dx.doi.org/10.30818/jpkm.2018.2030104.

26 Ika Rusdiana, "Kognisi Pembaca Berita Palsu (Fake News) Di Media Online," Kodifikasia: Jurnal Penelitian Islam 12, no. 2 (December 31, 2018): 185-196-196, https://doi.org/10.21154/kodifikasia. v12i2.1520.

27 Ibrahim, "Pembentukan Masyarakat Madani Di Indonesia Melalui Civic Education," 134.the Islamic thinkers usually refers to the condition of civil society such as on the condition of Medina under the leadership of the Prophet Muhammad a ${ }^{1} \pitchfork$ allalläh $\hat{a} € \sim$ alayh wa Sallam. Ideal concept of civil society is driven by a variety of many aspects including the pattern of the life of society, nation that refers to the rule of law, human rights, and respect for diversity in all its forms (pluralism

28 Suroto Suroto, "Konsep Masyarakat Madani Dii Indonesia Dalam Masa Postmodern (Sebuah Analitis Kritis)," Jurnal Pendidikan Kewarganegaraan 5, no. 9 (May 1, 2016), https://doi. org/10.20527/kewarganegaraan.v5i9.316.

Mawardi, "Dimensi-Dimensi Masyarakat Madani,"159. 
to live in peace, mutual trust, and fullness. with tolerance so that a moral, equal and cultured society grows. The concept of civil society itself can be used as a reflection by society today and is a concept of society that is expected to grow and develop and can guide the Indonesian nation in a better direction..

In building the life of civil society, (Muhamad AS. Hikam) in his book "Democracy and Civil Soceity." as quoted by Ibrahim in his journal that a society must have several characteristics such as sincerity, freedom, trust and independence which are tied to values and legal norms that are obliged to be obeyed by all members of society.. ${ }^{30}$ Therefore, further research by Charis and Alfian regarding the existing discourse on civil society is important in shaping a civilized yet democratic society.. ${ }^{31}$ Furthermore (Ilma and Alfian 2020) in their journals explains that the word / conception of "Islamic" with the term Civil Society is very important to be used as an offer or proposal in making changes. Civil society can thus be shaped by creating the ideal society that all nations and countries aspire to. The development of civil society in this regard in the era of the Industrial Revolution 4.0 as it is today requires a variety of materials that are sturdy and resilient based on the foundation of high religious values (religion). The key to the building is none other than Islamic Education. Islamic education is an effort to create a superior and Islamic generation which in turn will unite itself in forming a religious, moral, quality, and innovative and creative society in building a nation's civilization.. ${ }^{32}$

According to Ibrahim's view in his journal on pages 136-138, there are several characteristics that form the basis of a civil society, it is a unity that cannot be separated from one another, including the free public sphere, democracy, tolerance, pluralism and social justice.

a. Free Public Sphere namely, where in the concept of civil society there is a means of public space that can be used by the community to be able to freely express their opinions called the free public sphere. In this public

30 Ibrahim, "Pembentukan Masyarakat Madani Di Indonesia Melalui Civic Education," 135.the Islamic thinkers usually refers to the condition of civil society such as on the condition of Medina

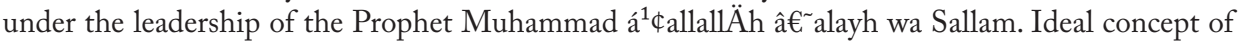
civil society is driven by a variety of many aspects including the pattern of the life of society, nation that refers to the rule of law, human rights, and respect for diversity in all its forms (pluralism

31 Irfan Charis and Mohamad Nuryansah, "Pendidikan Islam Dalam Masyarakat Madani Indonesia," MUDARRISA: Jurnal Kajian Pendidikan Islam 7, no. 2 (December 31, 2015): 229-58, https://doi. org/10.18326/mdr.v7i2.229-258.

32 Mughniatul Ilma and Rifqi Nur Alfian, "Konsepsi Masyarakat Madani Dalam Bingkai Pendidikan Islam," MA'ALIM: Jurnal Pendidikan Islam 1, no. 01 (September 2, 2020), https://doi.org/10.21154/ maalim.v1i01.2186. 
sphere, every member of society has the right and is free to express their opinion without fear of twisting the facts. Society in the public sphere is not bound by the influence of the government or the state due to the influence of developing democracy, so that the opinions that emerge can become material for deliberation and material for debate for the community itself.. ${ }^{33}$ So that citizens have the right to express opinions, fight together, discuss and convey information to the public. This free public sphere must be given great attention because it is a prerequisite for building a civil society that has the means of public space to express opinions without being regulated by the authorities or the government.

b. Democratic, where the driving force in the development of civil society is democratic behavior, in which every society has absolute freedom in carrying out its daily activities, especially in terms of interacting or relating to other communities. Having polite behavior in dealing or interacting with fellow people in their environment regardless of differences in religious, ethnic or cultural status is a reflection of democratic behavior. Democracy in building civil society is not just political democracy, but in all aspects such as social, economic, cultural, religious, educational, and others. So important is this democratic behavior that it is one of the prerequisites for realizing civil society.

c. Tolerant, in this case a tolerant attitude is an attitude that must be instilled in the life of civil society, this aims to create an attitude of mutual understanding and respect for everything that is done by others. The various conditions of society such as differences in ethnicity, religion, race, and class lead to the importance of tolerance, because with an attitude of tolerance, people are aware and will try to respect all existing differences without causing problems that lead to division. Azra as quoted by Ibrahim in his study said that civil society is not just a pro-democracy step. Thus, a tolerant attitude is a condition that must be met in a civil society. ${ }^{34}$

33 Ibrahim, "Pembentukan Masyarakat Madani Di Indonesia Melalui Civic Education," 136.the Islamic thinkers usually refers to the condition of civil society such as on the condition of Medina under the leadership of the Prophet Muhammad á ${ }^{1}{ }$ allalläh $\hat{a} € \sim$ alayh wa Sallam. Ideal concept of civil society is driven by a variety of many aspects including the pattern of the life of society, nation that refers to the rule of law, human rights, and respect for diversity in all its forms (pluralism

34 Ibrahim, 137.the Islamic thinkers usually refers to the condition of civil society such as on the

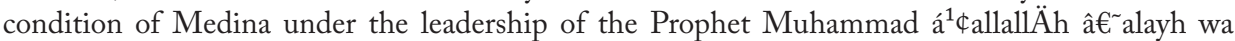
Sallam. Ideal concept of civil society is driven by a variety of many aspects including the pattern of the life of society, nation that refers to the rule of law, human rights, and respect for diversity in all its forms (pluralism 
d. Pluralism, in this case, is a prerequisite for the growth of civil society, which is understanding the meaning of pluralism. Every human being in a group of society will not all be the same, both in attitude and behavior. Especially in a large group of people, in which there is a diversity of ethnicities, religions and groups, so that every society must recognize and respect the diversity that exists in their lives, mutual understanding and understanding are needed in a pluralistic society. By respecting pluralism, people will grow in peace and harmony without anyone feeling superior to other communities.

e. Social Justice, with this concept, balance in exercising rights and obligations as a member of society is a prerequisite that cannot be ignored, because social justice contains national values. There should not be any part of the community who are treated preferentially while others are treated casually. All people in all aspects of their lives must be treated equally, so that monopoly efforts are not formed in the aspects of the life of the nation and state. Thus, an egalitarian society is born, that is, having the same degree with one another. Based on the above study, paradigmatically, civil society is a dynamic that can harmonize human life in various different dimensions so that there is a meeting point between social, cultural and religious life in today's society, so that it will create an independent society full of values. -Human, cultural and religious values which are a prerequisite for realizing a society that has the same degree, is comprehensive and full of real balance. ${ }^{35}$

\section{The Dangers of Hoaxes in Building Civil Society}

The diversity of society in terms of ethnic plurality, ethnicity, economy, customs, religion or nation is something that can create a difference in a person's perspective in realizing his desires and carried out in accordance with the view of life he believes. The person's point of view will be influenced by beliefs and customs as well as several situational factors. According to Mawardi, that the existence of this difference in view requires attention and wise social control so as not to cause problems that occur in various groups of society. Because in building civil society, it requires security and peace as well as a holistic or comprehensive legal balance in every community group.

35 Ibrahim, 138.the Islamic thinkers usually refers to the condition of civil society such as on the condition of Medina under the leadership of the Prophet Muhammad á ${ }^{1}{ }^{\dagger}$ allalläh â $€^{\sim}$ alayh wa Sallam. Ideal concept of civil society is driven by a variety of many aspects including the pattern of the life of society, nation that refers to the rule of law, human rights, and respect for diversity in all its forms (pluralism 
According to Suroto's view ${ }^{36}$ that civil society or civil society can be interpreted as a motive for an organized community life, having the characteristics of volunteerism, self-reliance, independence, but has a high legal awareness. The concept of civil society deals with social changes that occur in society, so that in realizing it, there will be an active process involving the dynamics of relationships in the social structure and the values and norms in it. Thus, the development of social structures and values and norms in civil society must take into account the various dimensions that exist, such as in religion, culture, economy, politics and education. As we know, the discourse on civil society development is happening in Indonesia today. There are many discourses about Indonesian society who want to realize the life of civil society.

Furthermore Masroer and Darmawan ${ }^{37}$ In his research, it is explained that the desire of the people towards civil society is related to the process of restoring people's rights to participate in various state activities such as in politics, culture, economy and others. The discourse of civil society in Indonesia can be interpreted as the goal of community life which is expected because it has a state system and balances the power of the State. For this reason, in the realm of building the concept of civil society, it is necessary to understand society about the characteristics of civil society. In line with that, the public must have an attitude of mutual trust in each other, even more so in the government. Of course in every human being there will be different views and attitudes, but these differences must be directed to be uniform in order to create a beautiful plurality of diversity in diversity.

It can be ascertained that every country that wants to create this civil society has certain characteristics and different challenges. According to Malik Fajar, as quoted by Charis \& Nuryansah, ${ }^{38}$ In their journals, civil society in Indonesia must contain several characteristics, namely the first, according to the Pancasila precepts, the community must believe and obey God Almighty; second, Indonesian civil society must be able to understand and respect all plurality and differences of opinion and perspective between one another so as to create a democratic and civilized society; third, a society that recognizes and respects human rights and egality in every aspect of life; a law-conscious society; a society

\footnotetext{
36 Suroto, "Konsep Masyarakat Madani Dii Indonesia Dalam Masa Postmodern (Sebuah Analitis Kritis)," 671.

37 Masroer Jb and Lalu Darmawan, "Wacana Civil Society (Masyarkat Madani) Di Indonesia," Jurnal Sosiologi Reflektif 10, no. 2 (September 9, 2016): 35-64, https://doi.org/10.14421/jsr.v10i2.1157.

38

Charis and Nuryansah, "Pendidikan Islam Dalam Masyarakat Madani Indonesia," 251.
} 
that has global capabilities but is still aware of the prevailing values and norms; uphold the value of civilization that can be preserved and will remain attached to the next generation; and the last is the growth of a society that is aware of the importance of education that will never end and occur throughout life.

In addition to the characteristics that exist in civil society, according to Dede Rosyada, ${ }^{39}$ Furthermore, in concluding things that must be considered in building a civil society, namely the existence of interconnected prerequisites and constituting a unity that cannot be separated from one another, including the free public sphere or public space as a means of freedom of opinion; democratic behavior, in which every society has absolute freedom in carrying out its daily activities, especially in terms of interacting or relating to other communities; a tolerant attitude which aims to make people aware of and try to respect all existing differences without causing problems that lead to division; the attitude of understanding pluralism which is needed so that every society understands and understands each other in a pluralistic environment; and the last is social justice, which is in the form of balance in exercising rights and obligations as members of society. However, to build a civil society with the characteristics mentioned above is not easy. There are various kinds of obstacles and obstacles that must be overcome, especially with the state of society in Indonesia which is full of diversity and diversity. The challenges that must be overcome by the Indonesian people in order to realize civil society according to Abuddin Nata, namely, challenges in the world economy, social dynamics of society, and international competition.. ${ }^{40}$

It can be said that the condition of the Indonesian nation, which is plural and pluralistic and diverse, is prone to conflict. Various conflicts have occurred in Indonesia, not just conflicts caused by differences in ethnicity or class. Even today, many conflicts occur because of differences in views in matters of politics and religion that make people have a primordial attitude that thinks their beliefs are better than others. Someone will lead public opinion to a belief that he thinks is true, from this attitude it will cause the growth of fake news or hoaxes in the community. Various news and information come and go, used by someone who does not know whether it is true or just to make fame, or whether it is just a trick of the people who want to make trouble. This is an age where information can be disseminated and received easily through advanced technology, a time where communication and interaction can be carried out without limits. An era where

\footnotetext{
39 Dede Rosyada, Pendidikan Kewarganegaraan (Civic Education): Demokrasi, Hak Asasi Manusia Dan Masyarakat Madani (jakarta : Prenada Media dan ICCE UIN Syarif Hidayatullah, 2003), 247. 
someone can "meet" (muwajjahab bil wujub) in the same world face without face to face. ${ }^{41}$

So that many people take advantage of technological sophistication for negative things, one of which is in spreading hoaxes. Allcott and Gentzkow in their research interpret hoaxes as news articles that are intentionally written to influence readers about the existence of false information so that readers will be influenced and take action based on fake news that is spread which ultimately misleads and terrorizes the readers. ${ }^{42}$ Hoax itself according to Mujib ${ }^{43}$ is a very dangerous thing for people who want to create civil society. The concept of a civil society that is democratic and free of opinion if it is filled with hoaxes will lead to deviant public behavior. Because, the impact of the spread of hoax news will affect the public's view of an issue, so they cannot distinguish which news is real or fake news which causes them to be incited by the spread of fake news. The spread of hoax information is very detrimental to the public because in addition to causing slander and fake news, hoaxes have also divided the public, both on behalf of political interests and certain religious organizations, with the aim of influencing public opinion.

In the end, the free public sphere which was used as a means of freedom of opinion did not work well, thus giving birth to a country that was not democratic, full of intolerance and resulted in divisions. With advances in science and technology in particular it will facilitate the spread of hoaxes. In addition, with the internet and social media, everyone can spread various kinds of positive things that exist in a person with the aim of getting recognition and praise from others. According to Pranoto ${ }^{44}$ In his research, it was explained that this behavior would be dangerous if someone had the desire to be popular without considering the content of the posts he spread. In other words, people will easily share information on social media that gives birth to narcissistic behavior in humans, which in fact will result in feelings of dissatisfaction when they do not do something which is said to be viral in the community. They are able to do various ways so that their popularity can be seen by others even at the expense of themselves or by spreading hoax information. This is one of the factors that

\footnotetext{
41 Sabiruddin, "Saring Sebelum Sharing, Menangkal Berita Hoax, Radikalisme Di Media Sosial."

42 Hunt Allcott and Matthew Gentzkow, "Social Media and Fake News in the 2016 Election," Journal of Economic Perspectives 31, no. 2 (May 2017): 211-36, https://doi.org/10.1257/jep.31.2.211.

43 Abd Mujib, "Pesan Al-Quran dalam Menyikapi Berita Hoax: Perspektif Dakwah di Era New Media," Jurnal Komunikasi Islam 7, no. 1 (2017): 42-65, https://doi.org/10.15642/jki.2017.7.1.42-65.

44 Pranoto, "Inspirasi Alquran dan Hadis dalam Menyikapi Informasi Hoax."
} 
hinders the growth of civil society in a society. In fact, the public can reduce various hoax information that occurs in simple ways, such as searching further on the source of the information read or by seeking additional information from other reliable sources such as in official media.

However, because people who want to be instantaneous and do not want to digest information first, they will easily be fooled by the fake news. This will cause distortion and the wrong view of society about an incident. And in no way reflect the characteristics of civil society. Besides that, Tsaniyah and Juliana ${ }^{45}$ mentions several ways to ward off hoaxes, namely by instilling eight main things in digital literacy, namely cultural (understanding the context), cognitive (increasing knowledge), constructive (creating positive new things), communicative (good at interacting and communicating), confident ( full of self-confidence and responsibility), creative (creative), critical (critical in responding to content), and civic (supporting the realization of civil society). Thus, the authors argue that the emergence and spread of hoaxes is very dangerous in the creation of civil society. The impact of the spread of hoax news will affect the public's view of an issue, so that they cannot differentiate between real news or fake news which in the end they are instigated by the fake news that spreads. The spread of hoax information is very detrimental to the public because in addition to causing slander and fake news, hoaxes have also divided the public, both on behalf of political interests and certain religious organizations, with the aim of influencing public opinion. ${ }^{46}$ In other words, the free public sphere, which is used as a means of freedom of opinion, will not work well, thus giving birth to a country that is not democratic, full of intolerance and divisions and far from the concept of civil society.

\section{Conclussion}

From the various descriptions that the author has conveyed above, in relation to the dangers of hoaxes in building civil society, it can finally be concluded as follows:

As we all know, civil society is something that is expected to grow in the life of society in the future because in it there is a concept of a society that is full of

$45 \quad$ Naimatus Tsaniyah and Kannisa Ayu Juliana, "Literasi Digital sebagai Upaya Menangkal Hoaks di Era Disrupsi," al-Balagh : Jurnal Dakwah dan Komunikasi 4, no. 1 (June 30, 2019): 121-40, https:// doi.org/10.22515/balagh.v4i1.1555.

46 Mujib, "Pesan Al-Quran dalam Menyikapi Berita Hoax."has given birth to the phenomenon of hoax, which is very disturbing for society. This is because the consequences of hoax messages are slanderous and attempts to disunite social groups. In response to this, the role of Islamic preacher (da'i 
holistic human values. Civil society is a characteristic of a group that is guided by the power of religion as the main source of moral values, ideas and ways of behaving within the diverse sphere of community life in order to be able to live in peace, mutual trust, and tolerance so that a moral, equal society can grow. and cultured. However, building civil society is not as easy as turning the palm of your hand, especially in the era of disruption / industry 4.0 like now where the era is very sophisticated (digital).

There are several prerequisites that must be met, including free public sphere or public space as a means of freedom of opinion; democratic behavior; tolerant attitude; attitude of understanding pluralism; and social justice. Where each of the requirements is interconnected and inseparable from one another. One of the challenges in building civil society in the 21st century is due to technological advances in which information can be disseminated and received easily through sophisticated technology, and communication or interaction can be carried out without limits, so that many people take advantage of technological sophistication for negative things. one of them is in spreading hoaxes. Hoax itself is a very dangerous thing for people who want to create civil society.

The concept of civil society in the era of the industrial revolution 4.0 as it is today which can be realized democratically and freely of opinion if it is filled with hoaxes will cause deviant public behavior. Because, the impact of the spread of hoax news will affect the public's view of an issue, so that people cannot distinguish which news is real or fake news which causes them to be incited by fake news that is spread. In the end, society was far from the concept of civil society because it gave birth to a country that was not democratic, full of intolerance and division.

\section{Reference}

Adhiarso, Dendy Suseno, Prahastiwi Utari, and Sri Hastjarjo. "The Influence of News Construction and Netizen Response to the Hoax News in Online Media." Jurnal The Messenger 10, no. 2 (July 31, 2018): 162-73. https://doi.org/10.26623/themessenger.v10i2.782.

Afrilia, Sella, Rumba Triana, and Syaiful Rokim. "Pandangan Al-Qur'an terhadap Realitas Hoax." Al- Tadabbur: Jurnal Ilmu Al-Qur'an dan Tafsir 3, no. 01 (June 7, 2018). https://doi.org/10.30868/at.v3i01.254. 
Allcott, Hunt, and Matthew Gentzkow. "Social Media and Fake News in the 2016 Election." Journal of Economic Perspectives 31, no. 2 (May 2017): 21136. https://doi.org/10.1257/jep.31.2.211.

Charis, Irfan, and Mohamad Nuryansah. "Pendidikan Islam Dalam Masyarakat Madani Indonesia." MUDARRISA: Jurnal Kajian Pendidikan Islam 7, no. 2 (December 31, 2015): 229-58. https://doi.org/10.18326/mdr.v7i2.229258.

Danial, and Warsiah. Metode Penulisan Karya Ilmiah. Bandung: Laboratorium Pendidikan Kewarganegaraan UPI., 2009.

Gandhi, Al Mutia. "Ancaman Hoax Terhadap Media Massa.” AL-HIKMAH: Media Dakwah, Komunikasi, Sosial Dan Budaya 9, no. 1 (June 25, 2018): 24-36.

https://doi.org/10.32505/hikmah.v9i1.1724.

Hikam, Muhammad AS. Demokrasi Dan Civil Soceity. Jakarta: LPES, 1996.

Ibrahim, Farid Wajdi. "Pembentukan Masyarakat Madani Di Indonesia Melalui Civic Education.” Jurnal Ilmiah DIDAKTIKA: Media Ilmiah Pendidikan Dan Pengajaran 13, no. 1 (August 1, 2012).

https://doi.org/10.22373/jid.v13i1.469.

Ilma, Mughniatul, and Rifqi Nur Alfian. "Konsepsi Masyarakat Madani Dalam Bingkai Pendidikan Islam.” MA'ALIM: Jurnal Pendidikan Islam 1, no. 01 (September 2, 2020).

https://doi.org/10.21154/maalim.v1i01.2186.

Jb, Masroer, and Lalu Darmawan. "Wacana Civil Society (Masyarkat Madani) Di Indonesia.” Jurnal Sosiologi Reflektif 10, no. 2 (September 9, 2016): 35-64. https://doi.org/10.14421/jsr.v10i2.1157.

Juditha, Christiany. "Interaksi Komunikasi Hoax Di Media Sosial Serta Antisipasinya Hoax Communication Interactivity in Social Media and Anticipation" Pekommas, Vol. 3 No. 1, April 2018: 31-44 (2018). http:// dx.doi.org/10.30818/jpkm.2018.2030104.

Lutfiyah, Khoirum. "Hoax and Fake News During Covid-19: Is the Law Effective in Overcoming It?" The Indonesian Journal of International Clinical Legal Education 2, no. 3 (September 30, 2020). https://doi.org/10.15294/ ijicle.v2i3.38422.

Mansur, Suraya, Nurhayani Saragih, Rajab Ritonga, and Novita Damayanti. "Fake News on Social Media and Adolescent's Cognition.” Jurnal ASPIKOM 
6, no. 1 (January 19, 2021): 29-41. https://doi.org/10.24329/aspikom. v6i1.827.

Mawardi, Imam. "Dimensi-Dimensi Masyarakat Madani: Membangun Kultur Etika Sosial." Cakrawala:Jurnal Studi Islam 10, no. 2 (December 15, 2015): 156-74.

Mujib, Abd."Pesan Al-Quran dalam Menyikapi Berita Hoax: Perspektif Dakwah di Era New Media.”Jurnal Komunikasi Islam 7, no. 1 (2017): 42-65. https:// doi.org/10.15642/jki.2017.7.1.42-65.

Muqsith, Munadhil Abdul, and Valerii Leonidovich Muzykant. "Effect Fake News for Democracy." Jurnal Cita Hukum 7, no. 3 (December 18, 2019): 307-18.

https://doi.org/10.15408/jch.v7i3.12956.

Nata, Abuddin. Akblak Tasawuf. Jakarta: PT Raja Grafindo Persada, 2000.

Ni'matuzzakiyah, Evi. "The Influence of Asmaul Husna Dhikr on Adolescent Emotional Intelligence." International Journal of Social Science and Religion (IJSSR), October 9, 2020, 47-54. https://doi.org/10.2020/ijssr.v1i1.7.

Pranoto, Stepanus Sigit. "Inspirasi Alquran dan Hadis dalam Menyikapi Informasi Hoax." AL QUDS : Jurnal Studi Alquran dan Hadis 2, no. 1 (June 22, 2018): 29-50.

https://doi.org/10.29240/alquds.v2i1.371.

Putri, Erti Fadhilah, Kukuh Setyo Pambudi, and Agus Adriyanto. "Analysis of the Increasing US-China Military Tension in the South China Sea and the Challenges for Indonesia." International Journal of Social Science and Religion (IJSSR), November 2, 2020,187-98. https://doi.org/10.2020/ijssr. v1i2.10.

Rasywir, Errissya, and A. Purwarianti. "Eksperimen Pada Sistem Klasifikasi Berita Hoax Berbahasa Indonesia Berbasis Pembelajaran Mesin.” Journal Cybermatika, 2016. /paper/Eksperimen-pada-Sistem-Klasifikasi-BeritaHoax-Rasywir-Purwarianti/1bccbbff6d80643ec3bfb0e6c27cf7c4e23fc18f. Rosmalinda, Ruri. "Fenomena Penyesatan Berita Di Media Sosial." Https:// Seskoad.Mil.Id, 2017.

Rosyada, Dede. Pendidikan Kewarganegaraan (Civic Education): Demokrasi, Hak Asasi Manusia Dan Masyarakat Madani. jakarta : Prenada Media dan ICCE UIN Syarif Hidayatullah, 2003.

Rusdiana, Ika. "Kognisi Pembaca Berita Palsu (Fake News) Di Media Online." Kodifikasia: Jurnal Penelitian Islam 12, no. 2 (December 31, 2018): 185196-196.

https://doi.org/10.21154/kodifikasia.v12i2.1520. 
Sabiruddin. "Saring Sebelum Sharing, Menangkal Berita Hoax, Radikalisme Di Media Sosial." AL MUNIR : Jurnal Komunikasi Dan Penyiaran Islam 0, no. 0 (June 1, 2019): 22-40. https://doi.org/10.15548/amj-kpi.v2i1.486.

Siswoko, Kurniawan Hari. "Kebijakan Pemerintah Menangkal Penyebaran Berita Palsu Atau 'Hoax.”' Jurnal Muara Ilmu Sosial, Humaniora, Dan Seni 1, no. 1 (May 10, 2017): 13-19.

https://doi.org/10.24912/jmishumsen.v1i1.330.

Suroto, Suroto. "Konsep Masyarakat Madani Dii Indonesia Dalam Masa Postmodern (Sebuah Analitis Kritis)." Jurnal Pendidikan Kewarganegaraan 5, no. 9 (May 1, 2016). https://doi.org/10.20527/kewarganegaraan.v5i9.316.

Susanto, and Muhamad Iqbal."Pengabdian Kepada Masyarakat Dalam Sinergitas Akademisi Dan TNI Bersama Tangkal Hoax Dan Black Campaign.” CARADDE: Jurnal Pengabdian Kepada Masyarakat 2, no. 1 (June 11, 2019): 8-16. https://doi.org/10.31960/caradde.v2i1.119.

Susilo, Muhammad Edy, Subhan Afifi, and Senja Yustitia. "Peran Organisasi Masyarakat Sipil Dalam Pemberantasan Hoaks.” Eksos LPPM 2, no. 1 (December 17, 2020): 10-18. https://doi.org/10.31315/eksos.v2i1.4150.

Sutantohadi, Alief. "Bahaya Berita Hoax Dan Ujaran Kebencian Pada Media Sosial Terhadap Toleransi Bermasyarakat." DIKEMAS (Jurnal Pengabdian Kepada Masyarakat) 1, no. 1 (2017). https://doi.org/10.32486/jd.v1i1.153.

Tsaniyah, Naimatus, and Kannisa Ayu Juliana. "Literasi Digital sebagai Upaya Menangkal Hoaks di Era Disrupsi." al-Balagh : Jurnal Dakwah dan Komunikasi 4, no. 1 (June 30, 2019): 121-40. https://doi.org/10.22515/ balagh.v4i1.1555.

Utami, Pratiwi. "Hoax in Modern Politics: The Meaning of Hoax in Indonesian Politics and Democracy." Jurnal Ilmu Sosial Dan Ilmu Politik 22, no. 2 (January 4, 2019): 85-97. https://doi.org/10.22146/jsp.34614.

Wicaksono, Raden Mas Try Ananto. "Review and Analysis of Current Responses to Covid-19 in Brazil and India: Period of January to July 2020." International Journal of Social Science and Religion (IJSSR), November 2, 2020, 81-112. https://doi.org/10.2020/ijssr.v1i2.11. 